\title{
Conservation Agriculture and Climate Change: Implications for Sustainable Rural Development in
} Sanyati, Zimbabwe

\author{
Munyaradzi Admire Dzvimbo ${ }^{1 *}$, Tinashe Mitchell Mashizha², Monica Monga ${ }^{1}$, Cornelias Ncube ${ }^{1}$ \\ ${ }_{1}^{1}$ Department of Development Studies, Lupane State University, Bulawayo, Zimbabwe \\ ${ }^{2}$ Community Capacity Building Initiative Centre for Africa (CCBICA), Kadoma, Zimbabwe \\ munyadzvimbo@gmail.com*, tmashizha@gmail.com,momodzvimbo@gmail.com,corneliasncube@gmail.com
}

\begin{abstract}
Zimbabwe is one of the most developed countries in Sub-Saharan Africa in that markets and rural industrialization are likely to function relatively well. Thus, Zimbabwe's agricultural sector has been severely affected by climate change. The worsening agricultural conditions have led to undernourishment of many in rural areas and this has drawn so much attention. Young women have turned into prostitution, in their bid to ensure the survival of their families. Farmers in rural areas depend heavily on rain-fed water and with rainfall variability and extreme weather patterns records, their livelihoods are being threatened. To cope with the adverse impact of climate change on rural development, different coping strategies and mechanisms are being implemented. The government, non-governmental organizations (NGOs) and the private sector have all introduced various programmes and projects at grassroots levels. The information used in this paper was gathered using data from interviews, questionnaires, and focused group discussion. This article explores how conservation agriculture being one of the coping strategies, has helped rural farmers to deal with climate change and how it has sustained rural development in Sanyati District.
\end{abstract}

Keywords: Climate Change, Conservation Agriculture, Rural Development, Livelihoods, Coping Strategies

\section{Introduction}

Zimbabwe was once regarded as the breadbasket of Africa but after witnessing almost two decades of recession, its agricultural production has declined living many in need of food. Small holder farmer's families have lived in hunger, with children under the age of ten years malnourished. Climate change and poor harvest has made the government to become dependent on international food aid. The majority of rural farmers depend on rain water for agricultural activities and with the changing climate, it has presented development challenges. It is in this realm that, climate change imposes constraints to food security and rural development especially in relation to smallholder farmers whose livelihoods mostly depend on rain-fed agriculture (Twomlow et al., 2008; Delgado et al., 2011; Dzvimbo, Monga and Mashizha, 2017). Negative impacts of extreme events such as floods and droughts are expected to be high in countries of the Global South's rural areas. In an era where climate change is central in rural development policies and practice, conservation agriculture (CA) appears to potentially contribute a lot in addressing the challenge of adapting to sustainable agricultural practices to climate change (Ngwira et al., 2012; Tilman, 2015). In this regard, conservation agriculture is claimed to reduce negative impacts of climate change by optimizing crop yields and profits while maintaining a balance between agricultural, economic, environmental benefits and rural development (Hobbs al., 2008; Tilman, 2015). Conservation agriculture has been adopted as an alternative to protect the livelihoods of farmers. More than 300000 small-scale farmers in Zimbabwe had adopted conservation farming (FAO 2010, ICRISAT 2013). Those who have adopted the system have doubled their harvest and others nearly tripped it. But is it the case with farmers in Sanyati area where soil is sandy and no longer fertile after years of growing the white gold "cotton"? This study seeks to establish weather CA reduces the impact of the changing climate and increase yields in Sanyati Distract.

Defining Conservation Agriculture and Climate Change: Conservation agriculture consists of three fundamental agro principles namely minimal soil disturbance, mulching of the soil surface and legume based cropping (Nkala et al., 2011). The International Crops Research Institute for the Semi-Arid Tropics (2013) further goes on by stating that conservation agriculture improves infiltration, improves soil fertility, reduces soil erosion and builds up soil organic matter. FAO (2001) indicated that conservation agriculture is a farming technology which improves and allows for efficient utilization of resources through its integration management of resources available combined with external inputs. Others refer conversation agriculture as zero tillage, conversation tillage, non-tillage and direct planting (Ereinstein, 1999, Fowler \& Rockstorm, 2001). The technology erodes enhances reduction in labour required for crop production at an estimate of 50 
percent especially for peasant farmers. Agricultural expects argues that conservation agriculture increase yields and this address the issue of food security, it reduces poverty as livelihoods are protected and conserve biodiversity. Conservation agriculture has made agriculture production to be resilient to climate change. Climate change is a long-term change in the statistical distribution of weather patterns over periods of time that range from decades to millions of years. It may be a change in the average weather conditions or a change in the distribution of weather events with respect to an average, for example, greater or fewer extreme weather events. Climate change may be limited to a specific region, or may occur across the whole Earth. The International Panel for Climate Change (IPCC, 2007) defines climate change as a long term change/trend in weather, generally over decades. Long term changes are in the average climate that is the annual average temperature or precipitation or in climate extremes such as the frequency of intense rainfall. Climate change may result from natural factors such as changes in the sun's energy, changes in the natural processes within the climate system such as ocean circulation changes or it can be as a result of human activities that change the atmosphere's setup that includes deforestation and burning of fossil fuels ( Reddy, 2015; Cahill et al., 2014).

\section{Literature Review}

History of Conservation Agriculture in Zimbabwe: The origins of Conservation Agriculture (CA) can be traced back to conservation tillage, a farming technique which was developed to respond to the degradation of agricultural production. Conservation tillage was developed to address soil erosion, which was particularly caused by wind and rain. Conservation tillage was applied as a practice within conservation concept of agriculture and in some places it worked well and in some places, the story was different. Henceforth, people started to understand the concept of not tilling the soil using machines, which become a major principal. CA gained its popularity and its main objective changed towards providing a favorable microclimate for soil life by protecting the soil surface from sun, rain and wind as well as providing feed for the soil micro and macro organisms (Friedrich and Kienzle, 2008; Giller et al., 2009). The beginnings of the non-tillage approach in Zimbabwe can be traced back to the establishment of non-ploughing trials of tobacco in the 1920's (Marongwe et al., 2012). It is argued that the Northern Rhodesian government had to introduce non-tillage approach because of land degradation and high cost of diesel and spare parts as a result of the sanctions imposed on them. Zimbabwe gained its independence in 1980, and an estimated 30 percent of commercial farmers had adopted the use of conservation tillage, with the first conservation farming basin being implemented in Musana communal lands by Brain Oldrieve. The implementation of conservation farming in Musana communal lands saw an increase in yields and a reduction in soil erosion which led to the components of reduce tillage and 30 percent mulch retention being promoted to the smallholder farmers (Oldrieve, 1993). In 1988, AGRITEX joined forces with GTZ and implemented a project known as Contill from 1989-1996. The aim of the project was to address the issue of soil loss, water run-off and declining yields. AGRITEX and GTZ developed three tillage methods which was practiced namely mulch ripping, clean ripping and tied ridging. Applying these three principles, CA has been adopted to different provinces and districts in Zimbabwe.

Climate Change in Zimbabwe: One of the biggest threats facing humankind today is climate change. Global development which has being made over the decades has being lost and developing countries are more vulnerable because of their low adaptive capacities. Reports suggest that climate change can increase potential erosion rates which reduce agricultural production by $10 \%$ to $20 \%$ or even more in some extreme cases (Delgado et al., 2011; Rurinda et al., 2013). Zimbabwe has not been spared to feel the adverse impact of climate change, with families in rural areas suffering more as they depends agro based livelihoods. With a population of sixty seven percent living in rural areas (Zimstat, 2014), Zimbabwe is fighting one of the greatest battle which is climate change. There is a great consensus that climate change is indeed a threat, and it has been recognized and accepted as a reality and it has pose environmental, social, political and economic consequences. The impacts of climate change in Zimbabwe are likely to put on hold the country's development and pose great risk to food security (GoZ, 2013; Dzvimbo, Monga and Mashizha, 2017). Socioeconomic activities, human health, water resources and infrastructure have faced negative effects of climate change. Plants and animals many are not able to cope with and adapt to the change in climate and this pose a serious threat to ecosystems (Brown et al., 2012). 
Zimbabwe lies in the semi-arid region and usually receives rains between mid-Novembers to April. The country is classified into five agro-ecological regions on the bases of the amount of rainfall received in each region (Vincent and Thomas, 1961; Mugandani et al., 2012). Region I and II receive more rain and agricultural activities decreases form Region I to V. Region IV and V have the lowest rainfall of below $650 \mathrm{~mm}$ and they are not suitable for crop production but good for livestock production. Records have shown that Zimbabwe's rainfall is on decrease and the country is now characterized with frequent droughts. The timing of rainfall is now uncertain. There is a shift on the onset of rains, increase in the frequency and intensity of heavy rainfall events, increase in the proportion of low rainfall years, decrease in low intensity rainfall events and increase in the frequency and intensity of mid-season dry spells (Unganai, 2009). Temperature is increasing by around 0.1 degrees Celsius (Government of Zimbabwe, 2013). The Zimbabwe Meteorological Service highlighted that daily minimum temperature have risen by $2.6{ }^{\circ} \mathrm{C}$ over the last century while daily maximum temperatures have risen by $2{ }^{\circ} \mathrm{C}$ during the same period. By the year 2050, predictions indicate that temperature will increase by 2.5 degrees Celsius. The country is experiencing more hot days and fewer cold days than before and the annual surface temperature has warmed by about $0.4 \mathrm{C}$ from 1900 to 2000 (Government of Zimbabwe, 2013). During the wet season, daytime temperatures have warmed more than night time temperatures. Zimbabwe's five agro- ecological regions have shifted with rainfall and crop production deteriorating in each region. Areas such Norton and Mhondoro have shifted from region II to region III (Mugandani et al., 2012) while Kwekwe has shifted from region III to IV.

Figure 1: Map of Zimbabwe showing the new Natural Regions

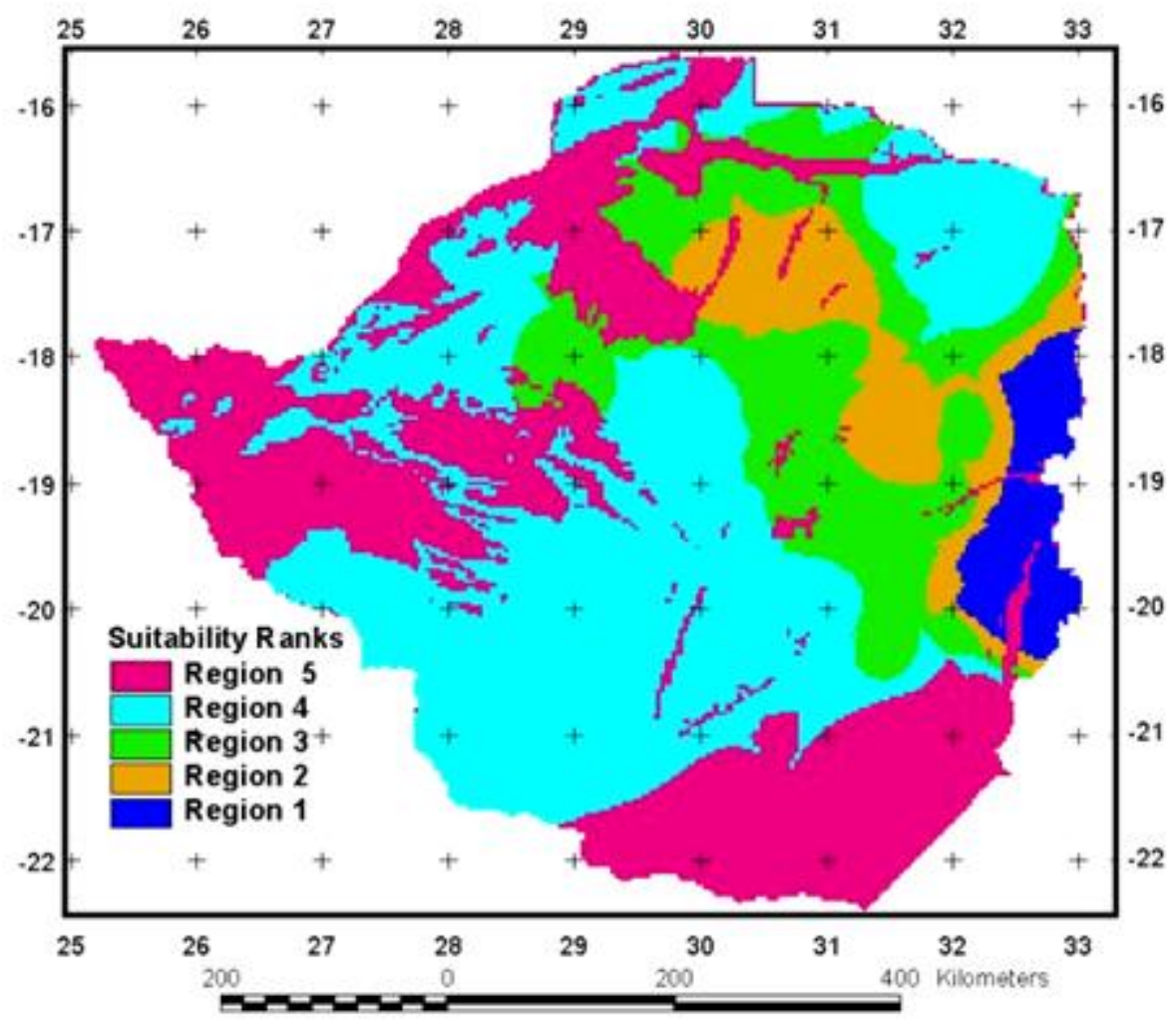

Source: Mugandani et al. (2012)

Conservation Agriculture and its relationship to Climate Change: The agricultural production of farming regions is being affected by climate change throughout the world. Economic Reforms that would help countries negatively affected by climate change could include the introduction of flexible land-use policies and the elimination of subsidies (Tilahun, 2013; Dzvimbo, Monga and Mashizha, 2017). Conservation agriculture is increasingly seen as the best practice to sustainable agriculture. The world is facing serious threats due to unreliable climate conditions hence; CA is a popular concept in rehabilitation response to emergencies caused by climate change induced disasters. Conservation agriculture focuses on soil organic 
matter which stabilizes soil and increase water holding capacity. Due to a direct relationship between soil and water conservation practices and maintaining and increasing productivity, research suggests that without the application of best soil and water conservation practices, it will not be possible to maintain the productivity levels that are needed to feed the additional billions of people by 2050 (Delgado et al., 2011). Conservation agriculture is an alternative management strategy which helps farmers to deal with a changing climate and it can allow for an increase in economic returns. Conservation agriculture assist in the adaptation to climate change by improving the resilience of agricultural cropping systems and hence by making them less vulnerable to abnormal climate situations (Friedrich and Kienzle, 2008). The farming method enhances better soil structures, due to minimum soil disturbance, and allow for high rate of water infiltration which reduces flooding. Conservation agriculture can increase the ability of smallholder farmers to adapt to climate change by reducing vulnerability to drought and enriching the local natural resource base on which farm productivity depends (Tilahun, 2013; Pannell et al., 2014). CA increases the level of organic matter within the soil which then improves the water holding capacity which is essential in drought periods. CA minimizes the release of green-house gases and it can retain carbon dioxide and store it for long periods, hence contributing to mitigate climate change.

CA is characterized by three fundamental agro principles namely minimum soil disturbance, mulching and legume- based cropping. Zero tillage is a system in which soil disturbance is reduced to sowing operations and traffic only and where weed control must be achieved by chemical means (Baeumer and Bakermans, 2008). This system enhances crops to be grown periodically with minimum disturbance of the soil, increase the amount of water that infiltrates and enhancing the cycling of nutrients in the soil. Mulching or soil cover is a process of spreading crop residues, dry grass and leaves on the field and it is a fundamental principle of CA. The effects of raindrops are minimized, thus reduce soil erosion and allow water to seep into the soil and reduce water evaporation. Studies which were conducted indicates that mulching moderates soil temperatures and others suggest that in the long run, mulching improve organic matter content and soil nutrients status. Crop rotation, a fundamental principle of CA helps in controlling weeds, diseases and pest by breaking their life cycles through the introduction of a new crop. Crop rotation is the most efficient and economical way to break the biological cycles of pests and diseases, thereby making Conservation Agriculture feasible (FAO, 2012; Ngwira et al., 2012).The mechanism reduces the risk of crop failure in cases of droughts.

\section{Methodology}

This study is a result of data collection procedures and analysis. The study adopted the use of semistructured interviews, questionnaires and focus group discussion. Data on climate change scenarios in Mashonaland West Province was obtained from the climatic records of the Zimbabwe Metrological Services Department. The data needed to be extended for a period of twenty-five years in order to be usable. A questionnaire survey was carried out in Alabama to capture the views and perceptions of households on climate change issues and households where selected randomly. Purposive sampling targeting the elderly of 50 years and above was adopted mainly to make significant comparisons with past climate. Interviews with Alabama farmers were conducted, to explore adaptive and mitigation strategies implemented to decrease agriculture's vulnerable to the impacts of climate change. Farmers who are more conservation oriented and early adopters of conservation agriculture were targeted mainly because the research team wanted to learn from people who had some experience and exposure with key conservation practices. There were twenty individuals from Pazvakavambwa Plots, villages 7- 15, village heads, and four representatives from local NGO who were interviewed. One interview using several questions guidelines was conducted by Rodrick Dick, the Director of Community Capacity Building Initiative Centre for Africa (CCBICA) a NGO involved in conservation and implementation in Sanyati District. Three focus group discussions were held to obtain more information on the views of men and women on the impacts of climate change based upon their experiences and possible coping strategies.

Study Area: The work was carried out in Alabama, south east of Kadoma. Alabama is a mining and farming village in the province of Mashonaland West, Zimbabwe. It is located about $20 \mathrm{~km}$ north of Kadoma. The area has red soil suitable to grow crops such as maize, soya beans, ground nuts and sorghum. 
Figure 3: Map Showing Kadoma, Sanyati District

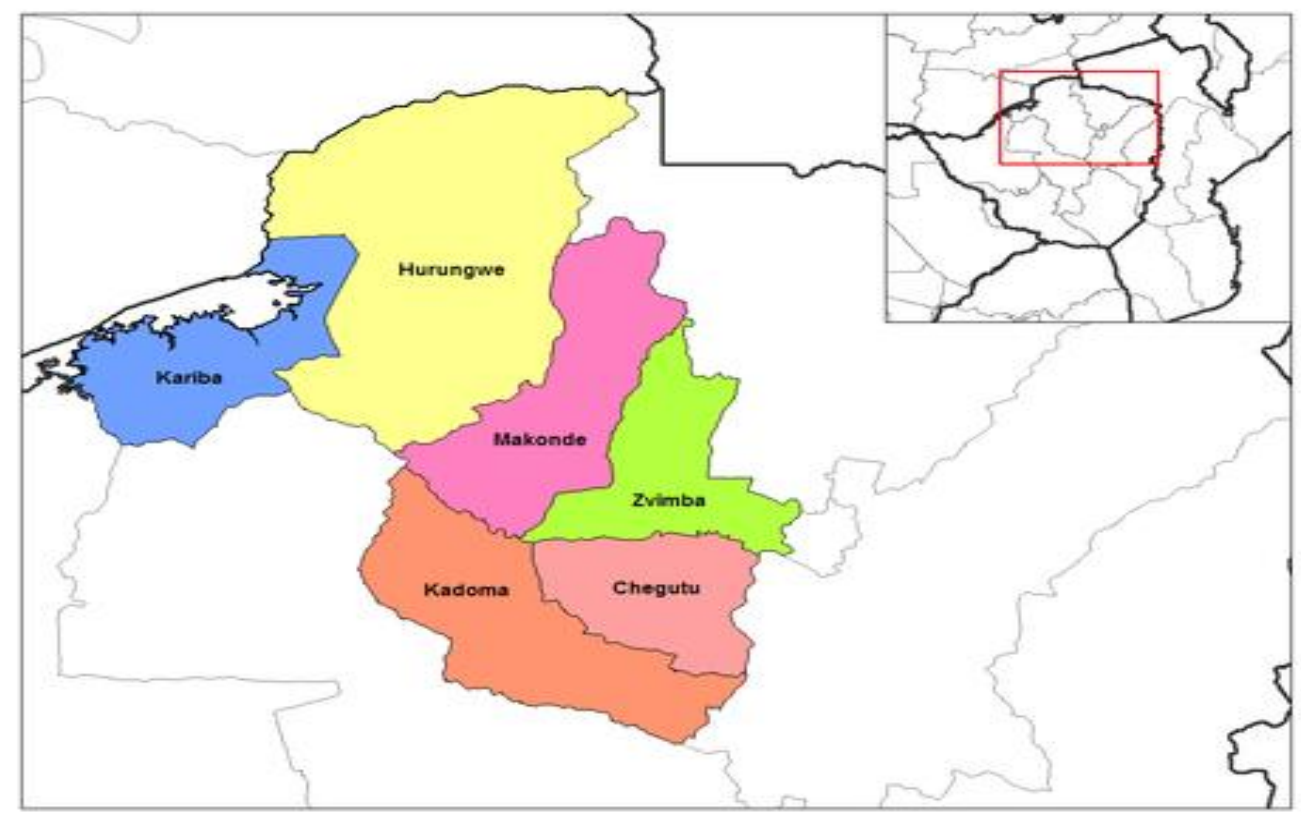

\section{Discussion}

Here, we present our discussion on how conservation agriculture acts as a buffer to climate change woes with special attention on sustainable rural development in Zimbabwe and taking cognizance of the various excerpts and components of the sustainable livelihoods framework as discussed in Jacobson et al. (1992). Various livelihood outcomes and conservation agriculture principles will be explored inter-alia climate change impacts, capital assets, and institutional arrangements on how to understand economic and agricultural systems, and various academics can dwell on the discourse. In all the study areas there was a general feeling that rainfall pattern has been decreasing during the last 30 years. At village level the concept of "climate change" was associated with weather conditions particularly rainfall unreliability and unpredictable over years rather than actual change.

CA as a buffer to Climate Change: Unpredictable weather patterns, unfertile poor soils and lack of institutional support are some of the factors responsible for affecting smallholder farmers in Sanyati district in Zimbabwe. This is supported by Rurinda et al. (2013) who states that farming of marginal and former commercial lands had declining soil fertility and low productivity levels worsened. In this regards, this study noted that agricultural production in rural areas has is being affected by climate change and that yields have declined. This is concurred by Baker et al. (2007); further argue that impacts of climate change are likely to reduce crop yields by 20 to $30 \%$ by 2050 in already marginal cropping regions thereby necessitating a shift from dependence on cropping to livestock as a livelihood option for most poor rural households. It is worth noting that since the year 2000, flooding has flooding has worsened farm productivity thereby increasing the vulnerability of smallholder farmers to both extreme rainfall patterns. This study revealed that floods and wild fires damage various infrastructures such as roads and bridges further compounding transportation problems of agricultural inputs, equipment and personnel to remote areas. Poor extension services provision, poorly organized farmers' organizations, poor means of transport, and insufficient housing for extension workers in the district also aggravate the vulnerability problem. Furthermore, farmers operate in inefficient product and credit markets characterized by highly distorted prices of both inputs and produce.

Coping with Climate Change in Sanyati District: In hot, dry Sanyati district, droughts are and community members highlighted that climate in the area is becoming drier with shorter growing seasons punctuated by mid-season dry spells. The study noted that rivers, streams, ponds and wetlands are drying up and pest populations are increasing. Locals have noted changes through their study on the behaviour of migratory 
birds (mashuramurove) and the flowering pattern of certain trees that they use to predict droughts and floods. This is supported by Icrisat (2013) who argues that indigenous knowledge system is used marginal communities to prepare and adapt to the changing climate. This study argues that short-term coping practices and long-term adaptive strategies based on indigenous knowledge are being adopted. These include social safety nets such as "the chief's granary" (Zunde raMambo) whereby the general community contributes to a grain store to help needy families during times of hard-ship. In addition nhimbe, or collective work, is carried out by community members.

Drought-coping measures: Community members interviewed revealed that wild fruit harvesting and dry planting before the rains have started are some of coping strategies they practise. Wild fruits that community members harvest includes mauyu, matamba and tsvubvu. It is worth noting that mauyu are used to prepare porridge to fed family members. The study noted that CA is highly adopted and households that were interviewed argues that the process increases productivity through higher crops yields. Households that adopt CA depend less on food aid and drought resilience. This is concurred by Twomlow et al. (2008) who reported that CA increase yields of up to 3.5 tonnes per hectare. CA technology is adopted as an insurance against drought as many families believe that the practise guarantees some level of yields even during years of drought.

Flood-coping measures: Traditional flood-proof building designs, temporary migration and dual-season cropping. Indigenous adaptation strategies can be used effectively in conjunction with conventional strategies through the participation of local community member.

Figure 4: Practicing of Conservation Agriculture

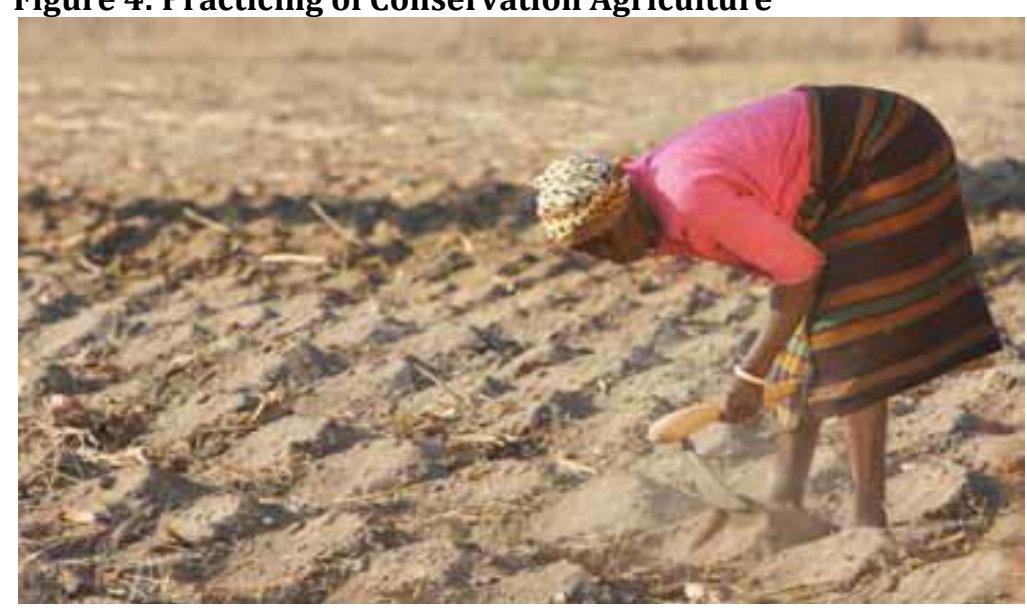

Source: ICRISAT

Drought Resistant Cropping: In line with the findings from this study through interviews, the immediate obtainable climate change strategy is drought cropping. Brown et al. (2012) puts forward that climate change will result in certain agro- ecological regions in Zimbabwe becoming unsuitable for maize production by 2050, as mean temperatures would have increased to 20 to 25 degrees Celsius and annual rainfall would have fallen to less than $450 \mathrm{~mm}$. Hence, with the bulk of communal farmers being in the low potential areas of agroecological regions IV and V, with limited irrigation potential and in field water harvesting techniques having varied results, drought resistant cropping is the most workable solution. More so, drought cropping is the quickest and most practical mechanism available to communal farmers mainly because it has the potential to alleviate food insecurity and poverty in the face of climate variability.

Planting small-grains: The study conducted interviews and FGD on 20 smallholder farmers who showed that communities are able to apply improvisation, experimentation and indigenous knowledge in small grains production as they have been doing for centuries. The communal farmers indicated that they have realised several advantages of small grains cropping over maize production. Small grains require minimal fertiliser, crop rotation and farmers can use open pollinated seeds and yield a reasonable harvest. Small grain crops are 
more resistant to pests and diseases, and when harvested, require less chemical treatment for storage (Ngwira et al., 2012).

Constraints and Challenges of CA implementation: Conservation agriculture has been successful in communities with fertile soils but its performance on poor degraded soils in Southern Africa remains unclear. As argued by Giller et al. (2009) the plough has become a symbol of agriculture such that many people involved including, farmers, extension agents, researchers, university professors and politicians find it difficult to believe that agriculture can be possible without tillage. Moreover, this study concludes that there is scepticism linked to the risk adverse disposition of the farmers leading to the reluctance in adopting revolutionary technologies attempting to change the paradigm of farmers. It is difficult to realize a paradigm shift especially on long established practices. The researchers of this study noted that success of CA depends on its ability to transform mindset of smallholder farmers and perceptions on how CA can lead to desired livelihood outcomes. As supported by Giller et al. (2009) the top-down approach in technology transfer is another constraint leading to questions whether CA addresses the needs of farmers, scientists or policymakers. Interventions and approaches to technology dissemination is failing due to lack of ownership by smallholder farmers. The demise of externally driven interventions is well documented and the introduction of CA in Southern Africa could face a similar fate.

Hobbs (2007) concurred as he states that constraints directly relate to the principles of CA, particularly the permanent soil cover with crop residues for moisture retention, increased soil biological activity and better protection of the soil. This study observed that farmers in Sanyati District collect crop residues and use them as stock feed not to cover the soil. Against this background, crop residues are removed by livestock that roam freely in the fields after harvesting. Hence, farmers are forced to face their fields such that they are able to keep crop residues and provide permanent soil cover. It is worth noting that some crop residues are decomposed by ants such that by the time the cropping season begins there will be no residues left in the field. Social harmony and justice seen as part of the social benefits of CA may be an anathema whose solution requires the involvement of all farmers. The shortage or late arrival of inputs, inexperienced personnel and inadequate access to government extension services is a common problem faced by smallholder farmers as supported by (Korstanje \& Cuenya, 2010). This paper argues that in remote communities, government agricultural extension services are unknown and have never visited some areas due to resource limitations. In some instances where extension services are provided, extension workers look at their involvement in the CA projects as extra work for which they should be remunerated separately. Since CA is a knowledge intensive technology, it would be difficult to successfully promote this technology without the help of welltrained and experienced extension workers. More to the above, small holder farmers faces financial constrains as they lack collateral to use and borrow from financial institutions. It is against this background that access to finance is a serious constraint to the implementation of CA by the targeted group of smallholder farmers in the region.

\section{Conclusion and Recommendations}

The study has shown that unpredictable weather patterns and lack of institutional support are determining factors responsible for affecting smallholder farmers in Sanyati District. This suggests that agricultural production is impacted by climate change and lack of institutional support has added more consequences on household livelihoods. Available evidence shows that conservation agriculture is a farming technique/ technology which reduce the negative impact of climate change. CA address the problem of low rainfall as it complement the use of technologies that reduces water losses and increase the soil moisture holding capacity. However, the adoption of CA is facing challenges. Smallholder farmers are reluctant to abandon the use of ploughs and some find it difficult to believe that agriculture can yield fruits without tilling the land.

This study raises the following policy implications:

- There is need for more information, education, trainings and communication strategy on the adaptation of CA and its impact on climate change.

- The Public and Private sector should building capacity of rural communication for adaptation and provide resources for them to participate in climate change adaptation activities with youths at the center of the process. More to the above, there is need to incorporate the use of Indigenous knowledge system in the climate change governance framework. 
- Reducing the length of the different phases in the adoption of CA could accelerate the realization of livelihood outcomes.

- It is vital to implement agricultural policies that put sustainable agriculture at the center, with appropriate donor and government support, incentives and institutional reform for effective transformation of farmers' productivity (Dzvimbo et al., 2017).

- Climate change communication provides additional climatic information that would enable farmers relate to conservation CA as an adaptation strategy.

- The implementation of CA should acknowledge and address the existing economic and ecological constraints facing farmers. Thus, smallholder farmers should be given an opportunity to adapt CA to their local conditions, experimenting with several components to assess what aspects of CA are suitable for them, how and when.

\section{References}

Baeumer, K. \& Bakermans, W. A. P. (2008). Advances in Agronomy. Journal, 2, 77-123.

Baker, C. J., Saxton, K. E., Ritchie, W. R., Chamen, W. C. T., Reicosky, D. C., Ribeiro, M. F. C., Justice, S. E. \& Hobbs, P. R. (2007). Tillage seeding in conservation agriculture, London: FAO and CAB International.

Brown, D., Chanakira, R. R., Chatiza, K., Dhliwayo, M., Dodman, D., Masiiwa, M., Muchadenyika, D., Mugabe, P. \& Zvigadza, S. ( 2012). Climate change impact, vulnerability and adaption in Zimbabwe, London: IIED.

Cahill, A. E., Aiello-Lammens, M. E., Reid, C., Hua, X., Karanewsky, C. J., Ryu, H. Y., Sbeglia, G. C., Spagnolo, F., Waldron, J. B. \& Wiens, J. J. (2014). Causes of warm-edge range limits: systematic review, proximate factors and implications for climate change. Journal of Biogeography, 41(3), 429-442

Delgado, J. A., Groffman, P. M., Nearing, M. A., Goddard, T., Reicosky, D., Lal, R., Kitchen, N. R., Rice, C. W., Towery, D. \& Salon, P. (2011). Conservation practices to mitigate and adapt to climate change. Journal of soil and water conservation, 66(4), 118-129.

Dzvimbo, M. A., Monga, M. \& Mashizha, T. M. (2017). The link between rural institutions and rural development: Reflections on smallholder farmers and donors in Zimbabwe. Journal of Humanities and Social Science, 22(6), 46-53.

Ereinsten, O. C. A. (1999). The economics of soil conservation in developing countries: The case of crop residue mulching, Unpublished PhD Thesis, Wageningen University, Netherlands.

FAO. (2001). High level panel on resource mobilization for food security and for agricultural and rural development, Rome: FAO.

FAO. (2010). Challenges and opportunities for carbon sequestration in grassland systems. Integrated crop management, Rome: FA0.

FAO. (2012). Crop rotation in conservation agriculture, Rome: FAO.

Fowler, R. \& Rockstorm, J. (2001). Conservation tillage for sustainable agriculture, an agrarian revolution momentum in Africa. Soil Tillage and Research, 61, 93-107.

Friedrich, T. \& J. Kienzle. (2008). Conservation agriculture: impacts on farmers' livelihoods, labor, mechanization and equipment, Pages 25-36 in Stewart, B.I., Asfary, A.F., Belloum, A. Steiner, K., \& Friedrich, T., editors. Conservation Agriculture for Sustainable Land Management to Improvethe Livelihood of People in Dry Areas, Proceedings of an international workshop, May 7-9, 2007,Damascus, Syria. Online: http://www.fao.org/ag/ca/CA-Publications/ACSAD\%202007.pdf. Accessed 12 December 2016.

Giller, K. E., Witter, E., Corbeels, M. \& Tittonell, P. (2009). Conservation agriculture and smallholder framing in Africa: The heretics' view. Field Crops Research, 23-34.

Government of Zimbabwe. (2013). Zimbabwe's National Climate Change Response Strategy, Harare: Government Press.

Hobbs, P. R., Sayre, K. \& Gupta, R. (2008). The role of conservation agriculture in sustainable agriculture, The Royal Society, DOI:10.1098/rstb.2007.2169

Hobbs, P. R. (2007). Conservation agriculture: what is it and why is it important for future sustainable food production? Journal of Agricultural Science, 145, 127-137.

ICRISAT. (2013). Conservation agriculture and micro-dosing in Zimbabwe, WREN.

IPCC . (2007). Climate Change 2007: Impacts, Adaptation and Vulnerability: Working Group II Contribution to the Fourth Assessment Report of the Intergovernmental Panel on Climate Change, Cambridge: Cambridge University Press. 
Jacobson, C., Keith, K. \& Kamel, T. (1992). Understanding soil ecosystem relationships, Brisbane: Queensland Department of Primary Industries.

Johansen, C., Haque, M. E., Thierfelder, C. \& Esdaile, R.J. (2012). Conservation agriculture for smallholder rained farming: Opportunities and constraints of new mechanism seeding systems. Field Crops Research, 132, 18-32.

Korstanje, M. A. \& Cuenya, P. (2010). Ancient agriculture and domestic activities: a contextual approach studying silica phytoliths and other microfossils in soils. Environmental Archaeology, 15(1), 43-63.

Marongwe, L. S., Nyagumbo, I., Kwazira, K., Kassam, A. \& Friedrich, T. (2012). Conservation Agriculture and Sustainable Crop Intensification: A Zimbabwe Case Study, Integrated Crop Management, 17-2012.

Mugandani, R., Wuta, M., Makarau, A. \& Chipindu, B. (2012). Re-classification of agro-ecological regions of Zimbabwe in conformity with climate variability and change. African Crop Science Journal, 20, 361369.

Ngwira, A. R., Thierfelder, C. \& Lambert, D. M. (2012). Conservation agriculture systems for Malawian smallholder farmers: long-term effects on crop productivity, profitability and soil quality. Renewable Agriculture and Food Systems, 28(4), 350-363.

Nkala, P., Mango, N., Corbeels, M. Veldwisch, G. T. \& Huising, J. (2011). The conundrum of conservation agriculture and livelihoods in Southern Africa. African Journal of Agricultural Research, 6(24), 55205528.

Oldrieve, B. (1993). Conservation Framing-A farm management handbook for communal, small-scale, resettlement and co-operative farmers in Zimbabwe, Harare: Mazongororo Paper Converters.

Pannell, D. J., Llewellyn, S. \& Corbeels, M. (2014). The farm-level economics of conservation agriculture for resource-poor farmers, Agriculture. Ecosystems and Environment, 187, 52-64.

Reddy, P. P. (2015). Climate Resilient Agriculture for Ensuring Food Security, India: Springer.

Rurinda, J., Mapfumo, P. \& Giller, K. E. (2013). Sources of vulnerability to a variable and changing climate among smallholder households in Zimbabwe: A participatory analysis. Climate Risk Management, 3, 65-78.

Tilahun, U. (2013). Farmers Perception of Climate Change and Conservation Agriculture in Western Ethiopia, Munich: GRIN Verlag.

Tilman, D. (2015). Food, Agriculture and the Environment: Can We Feed the World and Save the Earth? Fall, $144(4), 8-23$.

Twomlow, S., Urolov, J. C., Jenrich, M. \& Oldrieve, B. (2008). Lessons from the field - Zimbabwe's conservation agriculture task force. J SAT Agric Res, 6, 1-11.

Unganai, L. (2009). Adaptation to climate change among agro pastoral systems: Case for Zimbabwe, IOP Conf. Series: Earth and Environmental Science, 6(2).

Vincent, V. \& Thomas, R. G. (1961). An agro-ecological survey of Southern Rhodesia: Part I Agro-ecological survey, Salisbury: Government Printers.

Zimstat (2014). Compendium of statistics 2014, Harare: Government Printers. 